\title{
Digital Effects and Inequality of People's Quality of Life in the Globalization Era
}

\author{
Galina Litvintseva ${ }^{1, *}$, and Ilya Karelin $^{1}$ \\ ${ }^{1}$ Novosibirsk State Technical University, Faculty of Business, Department of Economic Theory and \\ Applied Economics, Prospekt K. Marksa 20, 630073Novosibirsk, Russian Federation
}

\begin{abstract}
.
Research background: Digital transformation are going on both in global economy and within separate states. This phenomenon became known as glocalization. In that respect the analysis of digitalization influence on people's quality of life in different regions of large-space countries like Russia seems to be actual.

Purpose of the article: Basing on calculation of digital component level of people's quality of life to estimate temporal and spatial effects affecting it, to determine inequality in digital components of quality of life in different regions of Russia.

Methods: Digital component of people's quality of life was computed basing on the authorial Russian regional index including six components. To estimate spatial and temporal effects panel data models were used. Digital inequality was found with the use of R/P $10 \%$ ratio, variation ratio and cluster analysisfor 2015-2018.

Findings \& Value added: The Russian regional index of digital component of quality of life was defined for 85 regions and increased by 0.051 in Russia. The first place is taken by safety of people informational activities while on the last one is quality of social sphere. Significance of temporal and regional factors in determining the influence of real gross regional product per capita on value of digital index is confirmed. Regional and temporal differences are characterized by digital inequality in Russian regions and components of people's quality of life. Digital transformation as a direction of globalization could both reveal effects and form new disproportions. Hence follows the importance of scientific justification of digital economy development programs.
\end{abstract}

Keywords: digital economy; quality of life; panel data model; regional effects; Russia.

JEL Classification: $C 33 ; F 63 ; O 15$

\footnotetext{
*Corresponding author: litvintseva-g@mail.ru
} 


\section{Introduction}

Modern processes of digital transformation develop both in the global economy and within separate states. Therefore along with the concept of globalization the glocalization term is used, it means that global and local processes are interconnected in influence on each other in different spheres of social development. This matter exhibited after the coronavirus COVID-19 pandemic beginning, especially in such areas as higher and secondary-level education, providing state services for people, in organizations using distant working places and so on. It is necessary to note that intercomplementarity of globalization and localization processes does not exclude their conflicts and negative consequences on national and regional levels.

Digital transformation of society significantly influenced on changes in people's quality of life (PQL). In that respect it seems to be actual to analyze the influence of digitalization on people's quality of life in different regions of such spacious countries like the Russian Federation (RF). Therefore the purpose of the article is to compute the level of digital component of people's quality of life, evaluation of temporal and spatial effects influencing on it as well as to discuss inequality of digital components of quality of life in different regions of Russia.

Globalization and digital transformation are studied in different aspects. Ambiguity of globalization effects was revealed by Dosi G., Roventini A. and Russo E. [1]. Influence, threatens and risks of globalization for different countries was considered by Dynkin A.A. [2], Cohen S.I. [3], Kalyugina S., Pyanov A. and Strielkowski [4]. Existence of decentralization and divergence processes was mentioned in papers by Muringani J., Fitjar R.D. and Rodriguez-Pose A. [5]. Direct research of glocalization processes was done by Arkhipov A.Yu. and Yeletsky A.N. [6], Okuma K. [7], interconnection of regional development was shown in works by Frangenheim, Trippl and Chlebna [8].

New trends in digital transformation, crisis and postcrisis processes were studied by Candelon B. et al. [9], Smyslov D. [10], Tintiangko J. and Soriano C.R. [11]. It is important to mention the papers which are connected to analysis of digital gaps, for example, Plotichkina N.V., Morozova E.V. and Miroshnichenko I.V. in Europe and Russia [12], Song Z. et al. in China [13], Blank G., Graham M. and Calvino C. in Great Britain [14].

We are interested not in global but in regional and interregional level within such spacious countries like the Russian Federation. It is necessary to mention interesting studies in that field like Arkhipova M. Yu. and Sirotin V. P. [15], Bufetova A. N. [16] as well as Gladkova A. and Ragnedda M. [17].

\section{Methods and database}

Digital quality of people's life is characterized by six components: digital quality of people, i.e. people having digital competences; availability of digital goods (computers, the Internet and so on) for people; digital quality of working life in conditions of digitalization (presence of computers, local information networks, electronic document flow in organizations etc.); quality of social sphere and services in conditions of digitalization (presence of information and communication technologies in education, health care, culture establishments, using the Internet to purchase goods and services); state electronic services for people (using the Internet for getting state and municipal services, assessment of their quality etc.); safety of people informational activities (using the tools of information protection by people, factors restraining use of the Internet by safety reasons). All these components were described by 34 positive and negative indicators selected as a result of correlation analysis. Using integral convolution a digital index was formed which was 
called by us the Russian regional index of digital component of people's quality of life (RRIDCPQL). The stages of its computation are described in detail in [18, 19].

The research uses the database created by the authors basing on the official data of the Federal State Statistics Service (Rosstat), this database includes general and digital indicators for 85 regions of Russia, 8 federal districts (FD) for the period of 2015-2018.

To evaluate spatial and temporal effects panel data models were used. Spatial regression models are widely used. In particular with the aid of them Naumov I.V. [20] studied dependence of gross domestic product on different elements of investment potential. $\mathrm{M}$. Kaneva and G. Untura [21] used dynamical panel regression and panel data model with spatial errors to study influence of Research and Development and knowledge dissemination on economic growth in Russian regions. In the given study the authors applied pulled regression and panel data model with fixed effects to evaluation of real gross regional product (GRP) per capita influence on the value of the Russian digital index in 2015-2018.

Digital inequality was defined with the use of $\mathrm{R} / \mathrm{P} 10 \%$ ratio and variation ratio for regions of federal districts of Russia as well as with the use of cluster analysis for the year 2018.

For computations and results visualization the software packages for statistical data processing such as SPSS Statistics, Microsoft Excel, program "Visualization of digital values sets on the map from the Excel figures" were used.

\section{Results}

\subsection{Assessment of people's digital quality of life in Russia in 2015-2018}

In 2018 comparing to 2017 the RRIDCPQL value increased from 0.506 to 0.516 . In the whole it increased by 0.051 during 2015-2017 (Fig. 1).

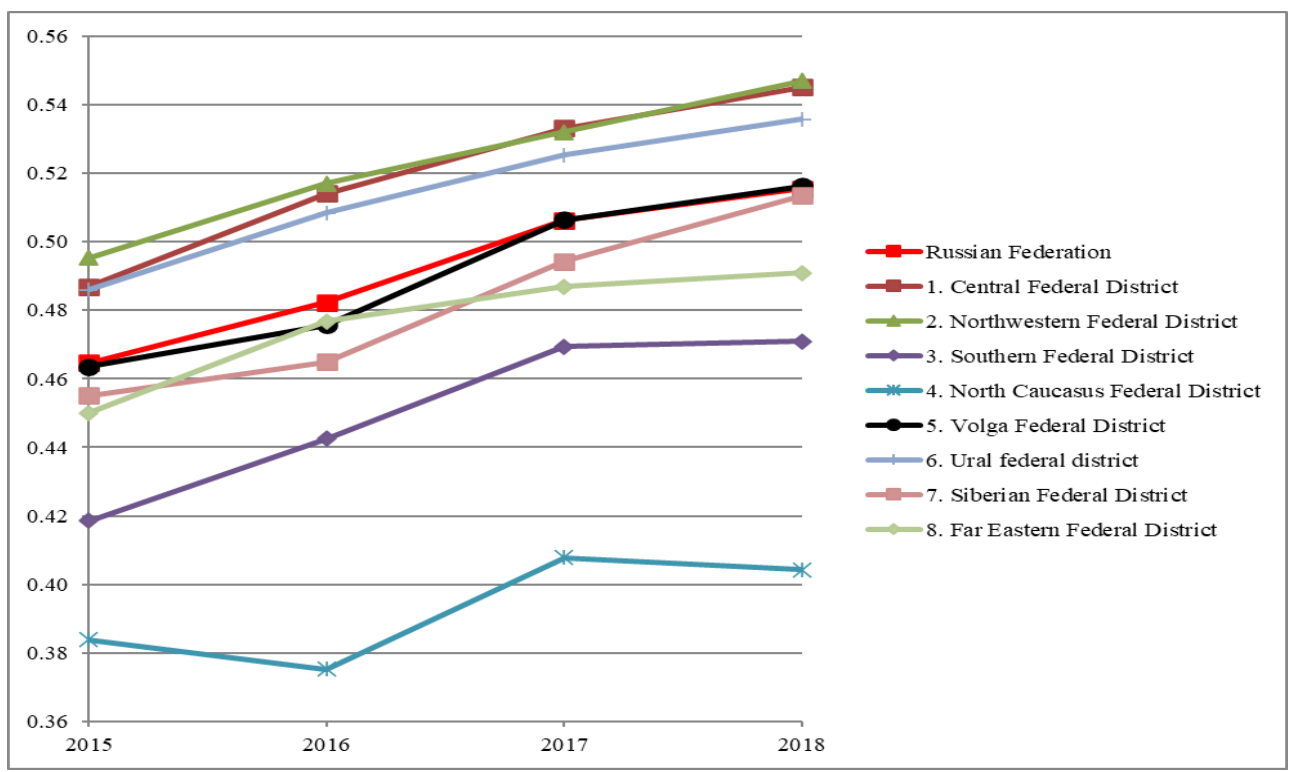

Fig. 1. RRIDCPQL dynamics in federal districts in 2015-2018. 
The North-Western federal district (FD) restored its first place and have maximal in Russia index value of 0.547 . The North-Caucasian FD constantly have the eighth position with the index value by 0.143 lower. The other FOs have quite stable ranges. Higher differentiation is in growth rates. In 2017-2018 all FOs had positive growth rates of the regional index of people's digital quality of life, excluding the North Caucasian FD (99.1\%).

The highest growth rates were found for the Siberian FD for all four years. Their values in 2018 comparing to 2017 and in 2018 comparing to 2015 were $103.9 \%$ and $112.8 \%$, respectively. The North-Western, Southern, Ural and Far Eastern federal districts changed their ranges in growth rates in different years. The five leaders in digital quality of life are the Yamalo-Nenets autonomous okrug (AO) (0.711), the city of Moscow (0.655), the Khanty-Mansiysk AO - Yugra (0.622), the Belgorod region (0.596), the Chuvash Republic (0.590), then follow the Tyumen region (0.575), the city of Saint-Petersburg (0.573).

The first place during all years of the considered period is taken by the subindex of safety of people informational activities, while the subindex of availability of digital goods is on the second one. The last place is steadily taken by the subindex quality of social sphere and services in conditions of digitalization.

\subsection{Interconnection between the digital index and real GRPs per capita}

At first let's consider the model of pulled regression reflecting interconnection between the digital index and real GRPs per capita and presented as a power function:

$$
R K Z N_{i, t}=A * R G R P_{i, t}^{\alpha} * \varepsilon_{i, t}
$$

In a linearized form we obtain the model 1:

$$
\ln \left(R K Z N_{i, t}\right)=\ln (A)+\alpha * \ln \left(R G R P_{i, t}\right)+\varepsilon_{i, t},
$$

where $R K Z N_{i, t}$ is the Russian regional index of digital component of people's quality of life

in the $i^{\text {th }}$ region in the year $t$ which is a ratio taking values from 0 to 1 ;

$R G R P_{i, t}$ is the real GRP per capita in the $i^{\text {th }}$ region in the year $t$ in comparable prices of the

year 2015, rubles / man;

A - unexplained remainder, a constant;

$\varepsilon_{i, t}$ - random measurement error;

$\alpha$ - the RRIDCPQL elasticity ratio on real GRP per capita, $\%$.

For the model 1 one a hypothesis was checked for the period of 2015-2018:

H0: real GRP per capita have statistically significant influence on the RRIDCPQL.

The results of computation presented in the table 1 tell about confirmation of the formulated hypothesis.

Table 1. Results of the model 1 parameters computation for the period of 2015-2018

\begin{tabular}{|l|c|c|c|}
\hline \multicolumn{1}{|c|}{ Parameter name } & $\begin{array}{c}\text { Evaluation } \\
\text { of parameter }\end{array}$ & Standard error & Significance \\
\hline Ln (A) & $-2.035^{* * *}$ & 0.106 & 0.000 \\
\hline$\alpha$ & $0.101^{* * *}$ & 0.008 & 0.000 \\
\hline Determination ratio & 0.305 & & \\
\hline F-criterion & 148.248 & & 0.000 \\
\hline Average approximation error, \% & 10.6 & & \\
\hline Number of observations & 340 & & \\
\hline
\end{tabular}

Note: ${ }^{* * *}$ - significance at $1 \%$ level, ${ }^{* *}$ - significance at $5 \%$ level, ${ }^{*}$ - significance at $10 \%$ level. 
The hypothesis H0 is confirmed as the ratio $\alpha$ is significant. Real GRP per capita has statistically significant influence on the RRIDCPQL in the whole during the period of 2015-2018.

The Breusch-Pagan test for heteroscedasticity gave the following results. The observed statistics value was 419.833, while the critical value was 28.698. Homoscedasticity hypothesis was rejected and heteroscedasticity hypothesis was accepted, which tells about dependence of errors dispersion on variables set characterizing region and time of observation.

Checking the test for linear limitations showed that observed statistics value was 30.369 and the critical statistics value was 1.421 . This means that it is necessary to proceed to the panel data model with fixed effects. Let us introduce dummy variables into the model which reflect temporal and regional differences.

Let's consider right along the model 2 in the linearized form:

$$
\ln \left(R K Z N_{i, t}\right)=\ln (A)+\left(\alpha+\sum_{i=2}^{85} \rho_{i} r_{i}+\sum_{t=2}^{4} \tau_{t} \text { year }_{t}\right) * \ln \left(R G R P_{i, t}\right)+\varepsilon_{i, t}
$$

where $r_{i}$ is a dummy variable of an $i^{\text {th }}$ region (except the Belgorod region which is taken as a normative one as it is the first in the list of the Russian regions in statistical books;

year $_{t}$ is a dummy variable for a $t^{\text {th }}$ year (from 2016 to 2018);

$\rho_{i}$ is change in the RRIDCPQL elasticity ratio on real GRP per capita due to regional differences in a region $i$; it shows change in elasticity ratio in an $i^{\text {th }}$ region comparing to the Belgorod region;

$\tau_{t}$ is change in the RRIDCPQL elasticity ratio on real GRP per capita due to temporal differences in a year $t$. It shows change in elasticity ratio in a $t^{h}$ year comparing to the year 2015.

For the model 2 several interconnected hypotheses were checked for the period of 2015-2018:

H0: real GRP per capita has statistically significant influence in the RRIDCPQL (for the Belgorod region);

H1: regional differences of other Russian regions have statistically significant influence on the influence degree of the real GRP per capita on the RRIDCPQL;

$\mathrm{H} 2$ : temporal differences have statistically significant influence on the influence degree of the real GRP per capita on the RRIDCPQL.

The results of computation presented in the table 2 tell about confirmation of the formulated hypotheses.

The hypothesis $\mathrm{H} 0$ is accepted as the ratio $\alpha$ is significant. Real GRP per capita has statistically significant influence on the RRIDCPQL during the period of 2015-2018 in the Belgorod region.

The hypothesis $\mathrm{H} 1$ is partially confirmed as some ratios $\rho_{i}$ turned to be significant. This means that regional unobserved factors have influence on the influence degree of real GRP per capita on the RRIDCPQL during the period of 2015-2018. In the regions where $\rho_{i}$ is greater than zero, GRP have higher influence on the RRIDCPQL. For example, the city of Moscow, the city of Saint Petersburg, the Chuvash Republic, the Kaliningrad region, the Tatarstan Republic and others. When $\rho_{i}$ are close to zero, then influence degree is at the same level as in the Belgorod region. When $\rho_{i}$ is less than zero then influence degree is lower than in the Belgorod region.

The hypothesis $\mathrm{H} 2$ is confirmed as all $\tau_{t}$ ratios turned to be significant. Temporal unobserved factors have positive influence on the influence degree of real GRP per capita on the RRIDCPQL during the period of 2015-2018. Dynamics of evaluations of this ratio shows that with each year the RRIDCPQL elasticity ratio on real GRP per capita grows by about $0.3-0.4 \%$. 
Table 2. Results of the model 2 parameters computation for the period of 2015-2018.

\begin{tabular}{|c|c|c|c|}
\hline Parameter name & Evaluation of parameter & Standard error & Significance \\
\hline $\operatorname{Ln}(\mathrm{A})$ & -2.145 & 0.091 & 0.000 \\
\hline$\alpha$ & 0.108 & 0.007 & 0.000 \\
\hline 2. Bryansk region & -0.005 & 0.002 & 0.000 \\
\hline 8. Kursk region & -0.006 & 0.002 & 0.000 \\
\hline 9. Lipetsk region & -0.006 & 0.002 & 0.006 \\
\hline 11. Oryol region & -0.006 & 0.002 & 0.002 \\
\hline 15. Twer' region & -0.008 & 0.002 & 0.003 \\
\hline 18. City of Moscow & 0.010 & 0.002 & 0.002 \\
\hline 19. Karelia Republic & 0.007 & 0.002 & 0.000 \\
\hline 21. Nenets autonomous okrug (NAO) & -0.020 & 0.002 & 0.000 \\
\hline 22. Arkhangel'sk region without NAO & 0.004 & 0.002 & 0.000 \\
\hline 24. Kaliningrad region & 0.005 & 0.002 & 0.000 \\
\hline 26. Murmansk region & 0.003 & 0.002 & 0.042 \\
\hline 27. Novgorod region & -0.005 & 0.002 & 0.012 \\
\hline 29. City of Saint-Petersburg & 0.004 & 0.002 & 0.092 \\
\hline 31. Kalmykia Republic & -0.009 & 0.002 & 0.009 \\
\hline 33. Krasnodar region & -0.010 & 0.002 & 0.025 \\
\hline 35. Volgograd region & -0.010 & 0.002 & 0.000 \\
\hline 38. Dagestan Republic & -0.033 & 0.002 & 0.000 \\
\hline 39. Ingushetia Republic & -0.004 & 0.002 & 0.000 \\
\hline 40. Kabardino-Balkar Republic & -0.015 & 0.002 & 0.000 \\
\hline 41. Karachai-Cherkess Republic & -0.006 & 0.002 & 0.069 \\
\hline 42. Norh Osetia republic - Alania & -0.013 & 0.002 & 0.000 \\
\hline 43. Chechen Republic & -0.009 & 0.002 & 0.003 \\
\hline 47. Mordovia Republic & 0.004 & 0.002 & 0.000 \\
\hline 48. Tatarstan Republic & 0.005 & 0.002 & 0.000 \\
\hline 50. Chuvash Republic & 0.015 & 0.002 & 0.051 \\
\hline 56. Samara region & -0.004 & 0.002 & 0.012 \\
\hline 57. Saratov region & -0.004 & 0.002 & 0.000 \\
\hline $\begin{array}{l}\text { 61. Khanty-Mansiysk autonomous okrug - } \\
\text { Yougra }\end{array}$ & -0.005 & 0.002 & 0.016 \\
\hline 63. Tyumen' region & 0.004 & 0.002 & 0.050 \\
\hline 66. Buryat Republic & -0.003 & 0.002 & 0.004 \\
\hline 67. Tyva Republic & -0.004 & 0.002 & 0.017 \\
\hline 68. Khakass Republic & -0.007 & 0.002 & 0.085 \\
\hline 70. Zabaykalye region & -0.011 & 0.002 & 0.029 \\
\hline 71. Krasnoyarsk region & -0.004 & 0.002 & 0.000 \\
\hline 72. Irkutsk region & -0.003 & 0.002 & 0.000 \\
\hline 77. Sakha Republic (Yakutia) & -0.014 & 0.002 & 0.017 \\
\hline 82. Magadan region & -0.015 & 0.002 & 0.072 \\
\hline 83. Sakhalin region & -0.008 & 0.002 & 0.000 \\
\hline 84. Jewish autonomous region & -0.006 & 0.002 & 0.000 \\
\hline 85. Chukotka autonomous okrug & -0.013 & 0.002 & 0.000 \\
\hline$\tau_{2016}$ & 0.003 & 0.001 & 0.003 \\
\hline$\tau_{2017}$ & 0.007 & 0.001 & 0.000 \\
\hline$\tau_{2018}$ & 0.008 & 0.001 & 0.000 \\
\hline Determination ration & 0.872 & & \\
\hline F-criterion & 45.514 & & 0.000 \\
\hline Average approximation error, $\%$ & 4.6 & & \\
\hline Number of observations & 340 & & \\
\hline
\end{tabular}

Note: ${ }^{* * *}$ - significance at $1 \%$ level, ${ }^{* *}$ - significance at $5 \%$ level, ${ }^{*}$ - significance at $10 \%$ level. 
In the whole growth of real GRP per capita have positive influence on the digital index despite regional and other differences presenting in Russian regions (Fig. 2).

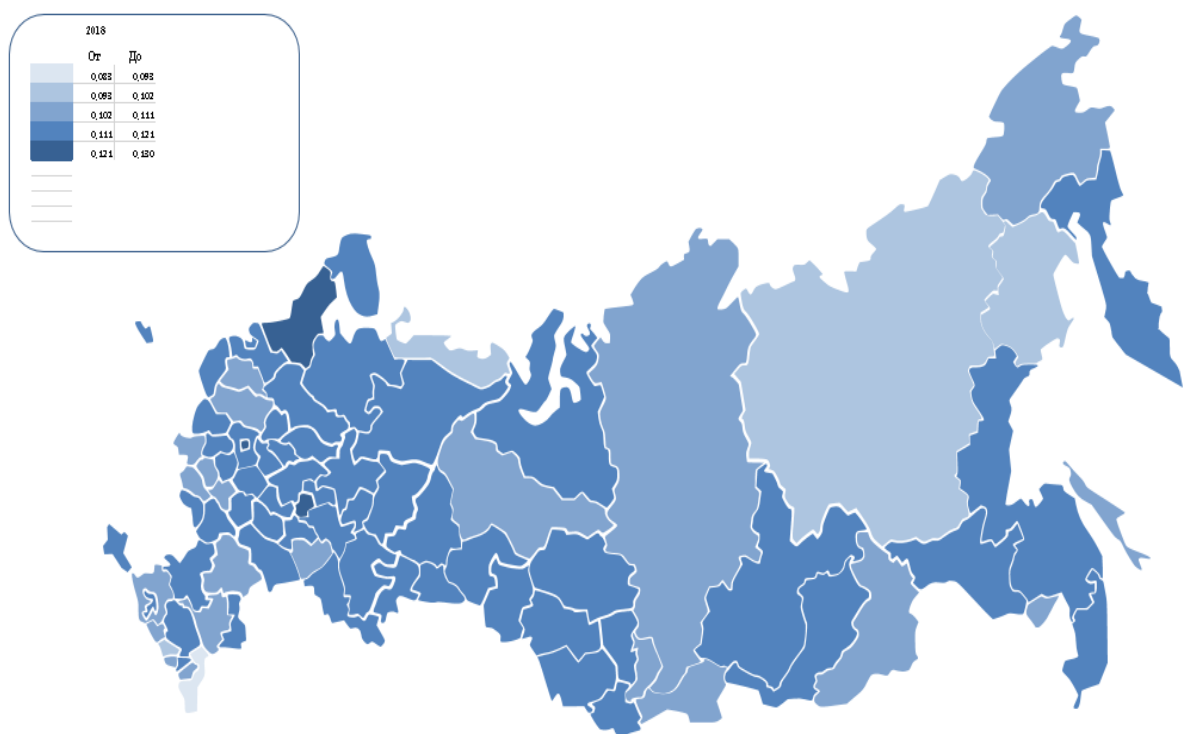

Fig. 2. The chart with Russian regions distribution of corrected elasticity ratios with consideration of regional and temporal differences for the year 2018.

Besides regional and temporal factors the RRIDCPQL is influenced by technological and institutional factors which are also have to be studied.

\section{Discussions}

Analysis of the digital index changes for federal districts showed significant differentiation of digitalization level of people's quality of life. While in 2018 its value (0.547) and growth rate $(102.8 \%$ to 2017$)$ in the North Western FD are higher than the Russian average ones $(0.516$ and $101.8 \%)$, they are notably lower for the North Caucasian FD (0.404 and 99.1\%). Ratios of digital inequality (R/P $10 \%$ ratio and variation ratio) computed by the authors for federal districts show decrease of their values for the years from 2015 to 2017 and some increase in 2018. Variation ratio varies from 3.7 to 14.5 within the four-year period, for Russia in the whole it decreased by $10.2 \%$ for the period and was 10.72 in 2018 . Higher values of variation ratio were in 2 federal districts: 13.58 in the North Caucasian FD and almost 14 in the Ural FD. The Yamalo-Nenets autonomous okrug which takes the first position in 2018 has digital regional ratio value of 0.711 , it is 2.37 times higher than similar ratio value for the Dagestan Republic (0.300).

In order to make a deeper research of the inequality 85 Russian regions were clusterized depending on the degree of digital component of PQL. The $k$-means method and the Ward method were used. Basing on RRIDCPQL values Russian regions could be divided into four clusters. According to the $k$-means method the first cluster includes two regions - the Yamalo-Nenets autonomous okrug and the city of Moscow. Their index values are greater than 0.65 . The second cluster for the year 2018 includes 45 regions with the index values ranged from 0.5 to 0.62 . The third cluster covers 37 regions with the index values from 0.4 to 0.5 . The fourth cluster includes 1 region - the Dagestan Republic (0.30) which has weak positions in all PQL blocks. Comparing to 2015 clusters composition changed positively. 
The number of regions in the first cluster did not change, but regions ranges altered as in 2015 and 2016 the first place was taken by the city of Moscow (the Central FD), while in 2017 and 2018 it was replaced by the Yamalo-Nenets autonomous okrug (the Ural FD). The second cluster included 30 regions in 2015, so their number increased by 15 by the year 2018. Respectively in the third cluster the number of regions contracted by 15 . The fourth cluster remained consisting of 1 region (Table 3 ).

Table 3. Number of share of regions in clusters in different federal districts of Russia in 2018 (the $k$ means method).

\begin{tabular}{|c|c|c|c|c|c|c|c|c|c|c|}
\hline \multirow{2}{*}{ Federal district } & \multicolumn{9}{|c|}{ Number of FD regions in cluster } & \multicolumn{5}{|c|}{ Share of FD regions in cluster, \% } \\
\cline { 2 - 13 } & 1 & 2 & 3 & 4 & Total & 1 & 2 & 3 & 4 & Total \\
\hline Central FD & 1 & 8 & 9 & 0 & 18 & 5.6 & 44.4 & 50.0 & 0 & 100 \\
\hline North-Western FD & 0 & 10 & 1 & 0 & 11 & 0 & 90.9 & 9.1 & 0 & 100 \\
\hline Ural FD & 1 & 4 & 1 & 0 & 6 & 16.7 & 66.6 & 16.7 & 0 & 100 \\
\hline Volga FD & 0 & 9 & 5 & 0 & 14 & 0 & 64.3 & 35.7 & 0 & 100 \\
\hline Siberian FD & 0 & 7 & 5 & 0 & 12 & 0 & 58.3 & 41.7 & 0 & 100 \\
\hline Far Eastern FD & 0 & 4 & 5 & 0 & 9 & 0 & 44.4 & 55.6 & 0 & 100 \\
\hline Southern FD & 0 & 3 & 5 & 0 & 8 & 0 & 37.5 & 62.5 & 0 & 100 \\
\hline North Caucasian FD & 0 & 0 & 6 & 1 & 7 & 0 & 0 & 85.7 & 14.3 & 100 \\
\hline Total & 2 & 45 & 37 & 1 & 85 & 2.4 & 52.9 & 43.5 & 1.2 & 100 \\
\hline
\end{tabular}

A steady trend of regions number increasing in the second cluster and decreasing in the third one could be traced. Regions of the North- Western, Ural, Volga and Siberian federal districts are mainly included in the second cluster. The large share of the Central, Far Eastern federal districts regions as well as those in the South of Russia are in the third cluster.

The Ward method gave in some way different results (Table 4).

Table 4. Number of share of regions in clusters in different federal districts of Russia in 2018 (the Ward method).

\begin{tabular}{|c|c|c|c|c|c|c|c|c|c|c|}
\hline \multirow{2}{*}{ Federal district } & \multicolumn{4}{|c|}{$\begin{array}{c}\text { Number of FD regions in } \\
\text { cluster }\end{array}$} & \multicolumn{4}{c|}{ Share of FD regions in cluster, \% } \\
\cline { 2 - 14 } & 1 & 2 & 3 & 4 & Total & 1 & 2 & 3 & 4 & Total \\
\hline Central FD & 1 & 8 & 8 & 1 & 18 & 5.6 & 44.4 & 44.4 & 5.6 & 100 \\
\hline North-Western FD & 0 & 10 & 1 & 0 & 11 & 0 & 90.9 & 9.1 & 0 & 100 \\
\hline Ural FD & 2 & 3 & 1 & 0 & 6 & 33.3 & 50.0 & 16.7 & 0 & 100 \\
\hline Volga FD & 0 & 9 & 5 & 0 & 14 & 0 & 64.3 & 35.7 & 0 & 100 \\
\hline Siberian FD & 0 & 7 & 3 & 2 & 12 & 0 & 58.3 & 25.0 & 16.7 & 100 \\
\hline Far Eastern FD & 0 & 4 & 5 & 0 & 9 & 0 & 44.4 & 55.6 & 0 & 100 \\
\hline Southern FD & 0 & 3 & 2 & 3 & 8 & 0 & 37.5 & 25.0 & 37.5 & 100 \\
\hline North Caucasian FD & 0 & 0 & 2 & 5 & 7 & 0 & 0 & 28.6 & 71.4 & 100 \\
\hline Total & 3 & 44 & 27 & 11 & 85 & 3.5 & 51.8 & 31.8 & 12.9 & 100 \\
\hline
\end{tabular}

The number of regions in the first cluster increased by 1 and in the fourth one - by 10 . However the majority of regions are in the second and in the third clusters with shares of $51.8 \%$ and $31.8 \%$ respectively. 3 regions from the Central and Ural regions are in the first cluster. Like the $k$-means method the Ward method gave worse results for southern regions. $71.4 \%$ of the North Caucasian FD regions are in the fourth cluster, but 6 regions of the Siberian, Southern and Central FDs have been added to them. 


\section{Conclusion}

The Russian regional index suggested by the authors allowed to evaluate people's digital quality of life on three levels (national, district and regional) and in the context of six components. It increased by 0.051 in Russia during 2015-2018. The first place is taken by safety of people informational activities and the last one - by digital quality of working life in conditions of digitalization. The North-Western federal district competes with the Central one for the first place and have maximal in Russia index value of 0.547 . The last eighth place is steadily taken by the North Caucasian FD with the index value by 0.143 lower.

Significance of temporal and regional factors was confirmed after defining the influence degree of real GRP per capita on the Russian digital index. Temporal and regional unobserved factors have significant influence on the impact level of real GRP per capita on the RRIDCPQL during the period of 2015-2018. It was revealed that due to the influence of temporal factors the RRIDCPQL elasticity ratio on real GRP per capita grows by approximately $0.3-0.4 \%$ per year. Elasticity ratios corrected with consideration of regional and temporal differences as on 2018 are positive.

Regional and temporal differences are characterized by digital inequality in Russian regions and components of people's quality of life. Variation ratio of the digital index changes from 3.7 to 14.5 within the four-year period. Higher degree of digital inequality was in the North Caucasus and Ural federal districts, it was also found for indices of digital quality of social sphere and digital quality of people.

So far digital transformation as a direction of globalization could both uncover potential effects and form new disproportions. Hence follows importance of scientific justification of digital economy development programs.

The reported study was funded by the Russian Foundation for Basic Research (RFBR) according to the research project № 19-010-00195\20.

\section{References}

1. Dosi, G., Roventini, A. and Russo, E. (2019). Endogenous growth and global divergence in a multi-country agent-based model. Journal of Economic Dynamics and Control, 101, 101-129.

2. Dynkin, A.A. (2020). International turbulence and Russia. Herald of the Russian academy of sciences, 90 (2),127-137.

3. Cohen, S.I. (2018). The Russian economy: new normal, past imbalances, future globalization. Journal of institutional studies, 10(1), 24-40.

4. Kalyugina, S., Pyanov, A. Strielkowski, W. (2020). Threats and risks of intellectual security in Russia in the conditions of world globalization. Journal of Institutional Studies, 12(1), 117-127.

5. Muringani, J., Fitjar, R. D., Rodriguez-Pose, A. (2019). Decentralisation, quality of government and economic growth. Revista de Economia Mundial, 51, 5-50.

6. Arkhipov, A.Y., Yeletsky, A.N. (2020). Modern globalization: development of glocalization and fragmentation of the world economy. International Journal of Sociology and Social Ppolicy, Early Access.

7. Okuma, K. (2019). Potential mechanisms for the social regulation of economies on global and local scales: an institutional analysis of ESG investment and community renewables. Evolutionary and Institutional Economics Review, 16(2), 523-541. 
8. Frangenheim, A., Trippl, M., Chlebna, C. (2020). Beyond the single path view: interpath dynamics in regional contexts. Economic Geography, 96(1), 31-51.

9. Candelon, B., Carare, A., Hasse, J.-B., Lu, J. (2020). The post-crises output growth effects in a globalized economy. International Economics, 161, 139-158.

10. Smyslov, D. (2019). Evolution of the world economy's globalization: contemporary trends. Mirovaya ekonomika i mezhdunarodnye otnosheniya [World Economy and International Relations], 63(2), 5-12. (In Russian).

11. Tintiangko, J., Soriano, C.R. (2020). Coworking spaces in the global south: local articulations and imaginaries. Journal of Urban Technology, 27(1), 67-85.

12. Plotichkina, N.V., Morozova, E.V., Miroshnichenko, I.V. (2020). Digital technologies: policy for improving accessibility and usage skills development in Europe and Russia. Mirovaya ekonomika I mezhdunarodnye otnosheniya [World Economy and International Relations], 64(4), 70-83. (In Russian).

13. Song, Z., Song, T., Yang, Y., Wang, Z. (2019). Spatial-temporal characteristics and determinants of digital divide in China: A Multivariate Spatial Analysis. Sustainability, 11(17), Article Number 4529.

14. Blank, G., Graham, M., Calvino, C. (2018). Local geographies of digital inequality. Social Science Computer Review, 36(1), 82-102.

15. Arkhipova, M.Y., Sirotin, V.P. (2019). Development of digital technologies in Russia: regional aspects. Ekonomika regiona [Economy of Region], 15(3), 670-683. (In Russian).

16. Bufetova, A.N. (2019). The study of spatial effects in regional dynamics of labor productivity. Region: Economy and Sociology, 2, 80-100. (In Russian).

17. Gladkova, A., Ragnedda, M. (2020). Exploring digital inequalities in Russia: an interregional comparative analysis. Online Information Review, 44(4), 767-786.

18. Litvintseva, G.P., Shmakov, A.V., Stukalenko, E.A., Petrov, S.P. (2019). Digital component of people's quality of life assessment in the regions of the Russian Federation. Terra Economicus, 17(3), 8-23. (In Russian).

19. Petrov, S., Maslov, M., Karelin, I. (2019). Digital component of people's quality of life in Russia. Studies in Business and Economics, 14(2), 115-126.

20. Naumov, I.V. (2019). Investigation of the interregional relationships in the processes of shaping the territories' investment potential using the methods of spatial modelling. Ekonomika regiona [Economy of Region], 15(3), 720-735. (In Russian).

21. Kaneva, M., Untura, G. (2019). The impact of R\&D and knowledge spillovers on the economic growth of Russian regions. Growth and Change, 50(1), 301-334. 